\title{
EFISIENSI PEMASARAN CABAI RAWIT MERAH DI DESA CIDATAR KECAMATAN CISURUPAN KABUPATEN GARUT
}

\author{
Adrianus Hia'), Rita Nurmalina2), dan Amzul Rifin ${ }^{3)}$ \\ 1) Kompas Gramedia, Jl. Sukamulya Sukasari Bogor Timur, Indonesia \\ 2,3) Departemen Agribisnis, Fakultas Ekonomi dan Manajemen, Institut Pertanian Bogor \\ Jl. Kamper Wing 4 Level 5 Kampus IPB Dramaga, Indonesia
}

1) E-mail: adrianushia@gmail.com

(Diterima 5 Maret 2019/ Disetujui 18 April 2019)

\begin{abstract}
The research marketing efficiency of red cayenne pepper was located in the Cidatar part of Cisurupan regency Garut district purposed to know marketing channel, marketing margin, and farmer's share. The research used descriptive analysis method. About 31 farmers were chosen with a random sampling method and with the snowball method to got 10 sellers. Interview and observation in collecting primary data while the documentation to retrieve secondary data. There are five red cayenne pepper marketing channels in Cidatar, Cisurupan District, Garut Regency. The marketing channels are, I) farmer - a collector - wholesaler Jakarta - retailer - consumer Jakarta; II) farmer - a collector - wholesaler Cikajang- retailer - consumer Cikajang; III) farmer - a collector - wholesaler Cikajang - wholesaler Jakarta - retailer - consumer Jakarta; IV) farmer - a collector - wholesaler Bandung - retailer - consumer Bandung; V) farmer - a collector wholesaler Bandung - wholesaler Jakarta - retailer - consumer Jakarta. The margin analysis results that the smallest marketing margin is in marketing channel II at 52,3 per cent. The largest Farmer's share is at 47 per cent in marketing channel II and the biggest ratio of $\pi i / C i$ is at 5,64 in marketing channel III. The suggestion that can be given to farmers is to choose marketing channel I because channel I am the channel with the great packing volume that may be delivered by the market and also the highest price compared to other marketing channels.
\end{abstract}

Keywords: farmer's share, marketing efficiency, marketing margin, red cayenne pepper

\begin{abstract}
ABSTRAK
Penelitian mengenai efisiensi pemasaran cabai rawit merah ini terletak di Desa Cidatar Kecamatan Cisurupan Kabupaten Garut dengan tujuan untuk mengetahui saluran pemasaran, margin pemasaran dan farmer's share. Penelitian ini menggunakan metode analisis deskriptif. Sebanyak 30 responden petani dipilih dengan metode random sampling dan untuk mendapatkan 10 responden pedagang menggunakan metode snowball. Wawancara dan observasi dalam mengumpulkan data primer sedangkan dokumentasi untuk mengambil data sekunder. Terdapat lima saluran pemasaran cabai rawit merah di Desa Cidatar, Kecamatan Cisurupan, Kabupaten Garut. Saluran pemasarannya adalah I) petani - pengumpul - pedagang besar Jakarta - pengecer - konsumen Jakarta; II) petani - pengumpul - pedagang besar Cikajang- pengecer - konsumen Cikajang; III) petani - pengumpul - pedagang besar Cikajang pedagang besar Jakarta - pengecer - konsumen Jakarta; IV) petani - pengumpul - pedagang besar Bandung - pengecer - konsumen Bandung; V) petani - pengumpul - pedagang besar Bandung - pedagang Jakarta - pengecer - konsumen Jakarta. Hasil analisis menunjukkan margin pemasaran terkecil terdapat pada saluran pemasaran II sebesar 52,3 persen. Farmer's share terbesar adalah 48 persen pada saluran pemasaran II dan rasio $\pi \mathrm{i} / \mathrm{Ci}$ terbesar adalah 5,64 pada saluran pemasaran III. Saran yang dapat diberikan kepada petani adalah memilih saluran pemasaran I karena saluran pemasaran tersebut merupakan saluran dengan volume cabai paling besar yang dapat diserap oleh pasar dan dengan harga yang paling tinggi dibandingkan dengan saluran pemasaran lainnya.
\end{abstract}

Kata Kunci: cabai rawit merah, efisiensi pemasaran, farmer's share, marjin pemasaran 


\section{PENDAHULUAN}

Tanaman sayuran memegang peranan penting dalam keseimbangan pangan, sehingga harus tersedia setiap saat dalam jumlah yang cukup dengan mutu yang baik, aman dikonsumsi, harga terjangkau serta dapat diakses oleh seluruh lapisan masyarakat. Cabai merupakan komoditas hortikultura dalam kelompok tanaman sayuran yang dibudidayakan, dikembangkan dan dikonsumsi oleh masyarakat luas untuk pemenuhan kebutuhan. Cabai mendapat perhatian serius dari pemerintah karena produk ini dikonsumsi masyarakat setiap hari dan tidak ada komoditas lain sebagai subsitusinya. Masalah yang sering dihadapi terkait produk ini adalah harganya yang sering berfluktuasi. Seringnya harga cabai yang naik maupun turun secara tajam menjadikan cabai termasuk dalam jajaran komoditas penyumbang inflasi yang terjadi setiap tahun.

Kebutuhan akan cabai rawit semakin meningkat seiring dengan meningkatnya jumlah penduduk. Konsumsi cabai rawit di rumah tangga pada periode 2002 - 2017 berfluktuasi namun cenderung meningkat (Kementrian Pertanian, 2018).

Pada tahun 2016, konsumsi cabai rawit mencapai $2.451 \mathrm{~kg} /$ kapita kemudian menurun menjadi sebesar $1.490 \mathrm{~kg} / \mathrm{kapita}$ pada tahun 2017 atau turun dengan rata-rata 39,19\%. Peningkatan konsumsi cabai rawit diprediksi masih akan terjadi hingga mencapai $2.030 \mathrm{~kg} / \mathrm{kapita}$ pada tahun 2020 atau naik 7,17\% dibandingkan tahun 2019 (Kementrian Pertanian, 2018).

Budidaya cabai rawit merah dilakukan secara musiman (seasonal) dengan umur panen sekitar 6-12 bulan. Biasanya petani cabai rawit merah melakukan budidaya setelah musim hujan atau pada bulan Desember - Januari sehingga panen raya terjadi sekitar bulan Juli hingga Agustus yang mengakibatkan harga komoditas menurun. Sedangkan pada saat musim hujan, produksinya akan menurun sehingga membuat harga cabai rawit merah melambung tinggi. Kemudian faktor lain yang mengakibatkan tingginya harga cabai rawit merah di pasar adalah faktor bencana alam seperti gunung meletus. Gunung meletus di Pulau Jawa mengakibatkan pasokan cabai rawit merah menurun drastis yang mengakibatkan harga melambung tinggi. Selain itu, tataniaga cabai rawit merah yang panjang membuat harga komoditas menjadi lebih mahal.

Desa Cidatar Kecamatan Cisurupan, Kabupaten Garut merupakan salah satu sentral produksi cabai rawit merah di Jawa Barat. Para petani cabai rawit merah di Desa Cidatarmemiliki ketergantungan dengan pihak pedagang pengumpul desa. Hal ini terjadi karena petani memerlukan modal yang besar dalam penyewaan alat transportasi untuk mendistribusikan cabai rawit merah langsung ke pasar. Kondisi ini melemahkan posisi tawar petani dalam penetapan harga yang dimanfaatkan oleh pedagang pengumpul desa untuk menetapkan harga produk pertanian secara sepihak. Selain itu, terbatasnya akses informasi pasar yang diterima petani menjadi masalah baru di mana saat harga cabai rawit merah dikonsumen akhir mengalami kenaikan namun kenaikan tersebut tidak diikuti dengan kenaikan harga di tingkat petani. Sistem pemasaran yang terbentuk diharapkan efisien karena sistem pemasaran dapat mempengaruhi

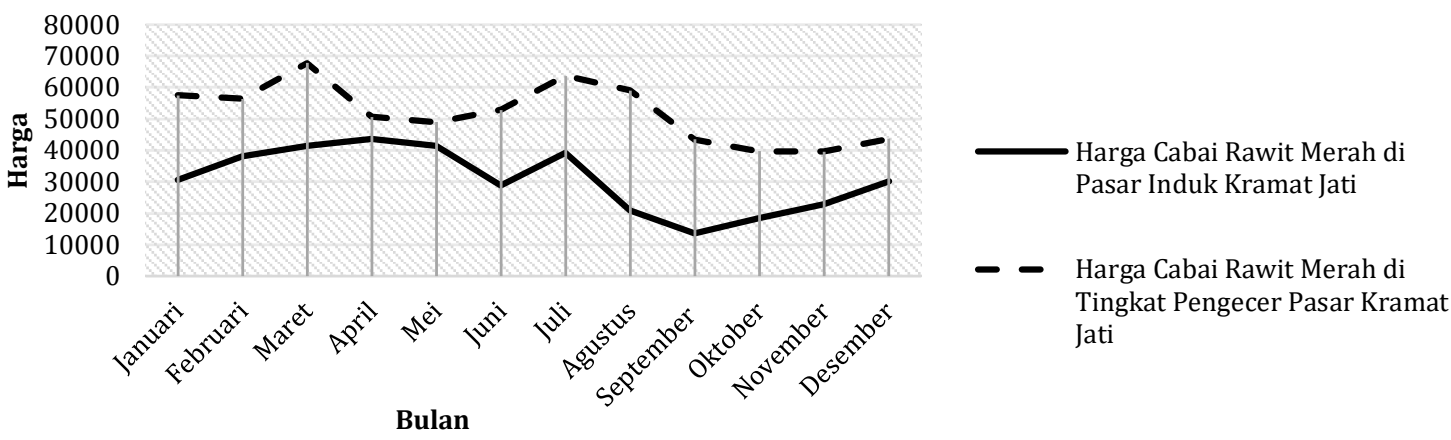

\footnotetext{
Gambar 1. Fluktuasi Harga Rata-Rata Cabai Rawit Merah di Pasar Induk Kramat Jati dan Pasar Kramat Jati Periode Januari 2018 - Desember 2018

Sumber: Bank Indonesia dan Pemerintah Provinsi DKI Jakarta (2018)
} 
pendapatan dan kepuasan tiap lembaga pemasaran yang terlibat. Petani melibatkan beberapa lembaga pemasaran dalam menyalurkan produk agar dapat menjangkau pasar yang lebih luas sehingga para petani cabai rawit merah diharapkan dapat memperoleh bagian harga yang memadai bagi peningkatan usahataninya.

Beberapa penelitian mengenai efisiensi pemasaran telah dilakukan, diantaranya Nurhidayana (2012) dalam penelitiannya yang berjudul analisis efisiensi pemasaran cabai merah di Kabupaten Batubara. Dalam penelitian ini, peneliti memperoleh kesimpulan bahwa saluran III merupakan saluran pemasaran yang paling efisien namun mayoritas petani menggunakan saluran I dalam memasarkan hasil panen cabai merah. Hal ini disebabkan volume cabai yang dipasarkan melalui saluran ini cukup besar mengingat tujuannya pemasarannya mencakup pedagang pengecer Kecamatan, Kabupaten dan Provinsi walaupun biaya pemasaran cukup besar.

Prayitno et al. (2013) dalam penelitian yang berjudul efisiensi pemasaran cabai merah di Kecamatan Adiluwuh Kabupaten Pringsewu Provinsi Lampung menemukan bahwa sistem pemasaran cabai merah di Kecamatan Adiluwuh Kabupaten Pringsewu Provinsi Lampung sudah efisien yang dapat dilihat dari pangsa pasar produsen yang lebih besar dari 70\%, walaupun struktur pasar yang terjadi adalah pasar yang tidak bersaing sempurna (oligopsoni). Perilaku pasar menunjukkan bahwa harga lebih banyak ditentukan oleh pedagang.

Puspita dan Wardhani (2013) menemukan bahwa semakin panjang saluran pemasaran maka semakin tidak efisien saluran pemasarannya hal ini karena biaya yang dikeluarkan semakin tinggi dan keuntungan yang diambil oleh masing-masing lembaga pemasaran semakin membuat harga cabai semakin tinggi. Peneliti juga menemukan bahwa pasar mengarah ke bentuk monopsoni.

Dewi et al. (2018) menyimpulkan bahwa saluran pemasaran yang paling efisien dari pemasaran jagung di Kabupaten Wonogiri adalah saluran pemasaran IV dengan melihat bahwa saluran IV memiliki persentase marjin pemasaran yang terendah.

Dari penjelasan tersebut maka tujuan dari penelitian ini adalah mengetahui saluran pemasaran, margin pemasaran, farmer's share pada masing-masing saluran pemasaran, dan efisiensi pemasaran cabai rawit merah di Desa Cidatar Kecamatan Cisurupan Kabupaten Garut.

\section{METODE}

\section{WAKTU DAN TEMPAT}

Penelitian ini dilakukan di Desa Cidatar Kecamatan Cisurupan Kabupaten Garut Provinsi Jawa Barat. Lokasi penelitian ini dilakukan secara sengaja dengan pertimbangan bahwa Jawa Barat merupakan sentral produksi cabai nasional terbesar kedua setelah Jawa Timur namun yang paling dekat dengan Pasar Induk Kramat Jati. Penelitian ini dilaksanakan pada Juni 2018 - Juli 2018

\section{PENENTUAN RESPONDEN}

Penentuan responden petani dilakukan secara acak sedangkan penentuan responden pengumpul desa, pedagang besar dan pengecer dilakukan dengan metode snowball sampling. Responden petani yang digunakan sebanyak 30 orang petani. Responden pedagang diperoleh dengan mengikuti alur pemasaran cabai rawit merah sesuai dengan informasi responden sebelumnya

\section{TEKNIK PENGUMPULAN DATA}

Penelitian ini menggunakan data primer dan data sekunder. Data primer diperoleh dari observasi lapangan dan wawancara langsung dengan responden sedangkan data sekunder diperoleh dari berbagai instansi/dinas dan literatur yang terkait dengan penelitian ini.

\section{ANALISIS DATA}

\section{ANALISIS SALURAN PEMASARAN}

Analisis saluran pemasaran dilakukan dengan menggambarkan pola atau saluran pemasaran cabai rawit merah di Desa Cidatar Kecamatan Cisurupan Kabupaten Garut.

\section{RASIO KEUNTUNGAN DAN BIAYA PEMASARAN}

Besarnya rasio keuntungan dan biaya pemasaran digunakan untuk mengukur efisiensi pemasaran. Semakin menyebarnya rasio keun- 
tungan dan biaya pemasaran maka sistem pemasaran semakin efisien. Untuk mengetahui penyebaran rasio keuntungan dan biaya pada masing-masing lembaga pemasaran dirumuskan sebagai berikut :

Rasio keuntungan dan biaya $=\pi / \mathrm{c}$

Keterangan:

$\Pi=$ Keuntungan lembaga pemasaran
$\mathrm{C}=$ Biaya Pemasaran

\section{MARJIN PEMASARAN}

Analisis marjin pemasaran akan dilakukan secara kuantitatif. Analisis ini berdasarkan pada data primer yang dikumpulkan dari setiap lembaga pemasaran mulai dari produsen sampai dengan konsumen. Selain itu, sebagai ukuran efisiensi pemasaran beberapa indikator yang dapat digunakan dan cara perhitungan dari Marjin pemasaran total (MT), marjin tiap lembaga tertentu yaitu Mi sehingga secara matematika akan diperoleh perhitungan sebagai berikut (Asmarantaka, 2014) ;

(1) $\mathrm{MT}=\mathrm{Pr}-\mathrm{Pf}$

(2) $\mathrm{MT}=\mathrm{C}_{\mathrm{i}}+\pi_{i}$

Dengan demikian diperoleh :

(3) $\operatorname{Pr}-\mathrm{Pf}=\mathrm{C}_{\mathrm{i}}+\pi_{i}$

Maka Besarnya marjin pemasaran dengan mempergunakan (1) dan (2) adalah sebagai berikut :

(4) $\mathrm{MT}=\sum \mathrm{M}_{\mathrm{i}}$

Dengan demikian marjin tingkat lembaga pemasaran ke-i adalah

(5) $\mathrm{M}_{\mathrm{i}}=\mathrm{Pj}_{\mathrm{i}}-\mathrm{Pb}_{\mathrm{i}}$

Keterangan :

MT = Margin pemasaran total

$\operatorname{Pr} \quad=$ Harga di tingkat konsumen $(\mathrm{Rp} / \mathrm{kg})$

$\mathrm{P}_{\mathrm{f}} \quad=$ Harga di tingkat petani $(\mathrm{Rp} / \mathrm{kg})$

$\mathrm{C}_{\mathrm{i}}=$ Biaya tataniaga pada lembaga pemasaran ke-i

$\pi_{i} \quad=$ Keuntungan lembaga akibat adanya sistem pemasaran

$\mathrm{M}_{\mathrm{i}}=$ Marjin pemasaran pada tingkat pemasaran ke-i, $i=1,2, \ldots, n$

$\mathrm{P}_{\mathrm{i}}=$ Harga penjualan lembaga pemasaran ke-i

$\mathrm{Pb}_{\mathrm{i}}=$ Harga pembelian lembaga pemasaran ke-i

\section{FARMER'S SHARE}

Farmer Share menurut Asmarantaka (2014) merupakan rasio antara harga ditingkat petani dengan harga di tingkat konsumen akhir atau retail untuk produk pangan dan serat. Dengan demikian FS, merupakan porsi dari nilai yang dibayar konsumen akhir yang diterima oleh petani dalam bentuk persentase (\%).

$$
\mathrm{FS}=\frac{\mathrm{Pf}}{\mathrm{Pr}} \mathrm{x} 100 \text { persen }
$$

Keterangan:

$\mathrm{P}_{\mathrm{f}}=$ Harga ditingkat petani $(\mathrm{Rp} / \mathrm{kg})$

$\mathrm{Pr}_{\mathrm{r}}=$ Harga ditingkat konsumen $(\mathrm{Rp} / \mathrm{kg})$

\section{HASIL DAN PEMBAHASAN}

\section{KARAKTERISTIK RESPONDEN PETANI}

Responden petani dalam penelitian ini adalah petani cabai rawit merah yang berada di wilayah Desa Cidatar yaitu sebanyak 30 petani. Berdasarkan data yang diperoleh menunjukkan bahwa umur petani responden di Desa Cidatar berkisar antara 30 - 63 tahun dengan kelompok usia tertinggi terdapat pada usia 31 - 40 tahun sebanyak 16 petani atau sebesar 52 persen. Kelompok usia ini termasuk ke dalam usia produktif atau usia kerja. Di desa ini juga terdapat petani dengan kelompok usia $\geq 61$ sebanyak 2 orang. Hal ini menggambarkan bahwa petani yang berusia relatif tua ( $\geq 61$ tahun) juga masih mampu untuk mengelola lahan.

Tabel 1. Karakteristik Responden Petani Berdasarkan Usia di Desa Cidatar

\begin{tabular}{ccc}
\hline $\begin{array}{c}\text { Kelompok } \\
\text { Usia (tahun) }\end{array}$ & $\begin{array}{c}\text { Jumlah } \\
\text { Responden } \\
\text { (Orang) }\end{array}$ & $\begin{array}{c}\text { Persentase } \\
\text { (\%) }\end{array}$ \\
\hline $31-40$ & 16 & 52 \\
$41-50$ & 7 & 23 \\
$51-60$ & 6 & 19 \\
$\geq 61$ & 2 & 6 \\
\hline Total & 31 & 100 \\
\hline
\end{tabular}

Sumber: Data Primer (2018) diolah

Petani responden memiliki tingkat pendidikan yang cukup rendah karena sebagian besar hanya meluluskan pendidikan di tingkat sekolah dasar. Persentase tertinggi pendidikan terakhir 
petani responden adalah sekolah dasar yaitu sebesar 71 persen. Jenjang SMP dan SMA/ sederajat masing-masing sebesar 13 persen dan 1 orang petani tidak bersekolah. Tingkat pendidikan petani ditampilkan pada Tabel 2 .

Tabel 2. Karakteristik Responden Petani Berdasarkan Tingkat Pendidikan di Desa Cidatar

\begin{tabular}{ccc}
\hline $\begin{array}{c}\text { Tingkat } \\
\text { Pendidikan }\end{array}$ & $\begin{array}{c}\text { Jumlah } \\
\text { Responden } \\
\text { (Orang) }\end{array}$ & $\begin{array}{c}\text { Persentase } \\
\text { (\%) }\end{array}$ \\
\hline Tidak Sekolah & 1 & 3 \\
SD & 22 & 71 \\
SMP & 4 & 13 \\
SMA & 4 & 13 \\
\hline Total & 31 & 100 \\
\hline
\end{tabular}

Sumber: Data Primer (2018) diolah

Rata-rata luas lahan yang digarap petani responden sebesar $1361 \mathrm{~m}^{2}$ dengan luas lahan terkecil adalah $25 \mathrm{~m}^{2}$ dan luas terbesar adalah 12 $000 \mathrm{~m}^{2}$. Data luas lahan petani responden dapat dilihat pada Tabel 3. Status kepemilikan lahan petani responden sebagian besar merupakan milik sendiri dengan persentase sebesar 90 persen dan 10 persen merupakan lahan sewa. Dalam hal pemasaran hasil panen, tidak ada perbedaan yang dilakukan oleh petani cabai rawit merah di Desa Cidatar karena semua hasil panen cabai rawit merah dijual ke para pedagang pengumpul desa.

Kebanyakan petani responden berjenis kelamin laki-laki (90 persen) dan hanya terdapat tiga petani yang berjenis kelamin perempuan (10 persen). Petani merupakan pekerjaan utama penduduk Desa Cidatar dan hampir semua kepala keluarga melakukan kegiatan pertanian sedangkan istri membantu suami untuk melakukan pemeliharaan dan pemanenan. Kegiatan pertanian juga dilakukan bersama anggota keluarga lainnya.

Tabel 3. Karakteristik Responden Petani Berdasarkan Luas Lahan di Desa Cidatar

\begin{tabular}{ccc}
\hline Luas Lahan & $\begin{array}{c}\text { Jumlah } \\
\text { Responden } \\
\text { (Orang) }\end{array}$ & $\begin{array}{c}\text { Persentase } \\
\text { (\%) }\end{array}$ \\
\hline$\leq 500$ & 12 & 39 \\
$501-1000$ & 5 & 16 \\
$1000-1500$ & 5 & 16 \\
$1501-2000$ & 1 & 3 \\
$\geq 2000$ & 6 & 19 \\
\hline Total & 31 & 100 \\
\hline
\end{tabular}

Sumber: Data Primer (2018) diolah

\section{KARAKTERISTIK PEDAGANG RESPONDEN}

Pedagang Responden yang diwawancarai terdiri atas pedagang pengumpul desa (PPD) sebanyak 5 orang, pedagang besar pasar induk 5 orang, pengecer 5 orang. Responden pedagang didominasi dalam usia produktif pada rentang usia 41-50 tahun (43,48\%), tingkat pendidikan didominasi lulusan SMA $(47,83 \%)$ dan SMP $(26,09 \%)$.

Tabel 4. Identitas Pedagang dalam Saluran Pemasaran Cabai Rawit Merah di Desa Cidatar Tahun 2018

\begin{tabular}{|c|c|c|c|c|c|c|}
\hline \multirow[b]{2}{*}{ Keterangan } & \multicolumn{2}{|c|}{ Pedagang Pengumpul } & \multicolumn{2}{|c|}{ Pedagang Besar } & \multicolumn{2}{|c|}{ Pedagang Pengecer } \\
\hline & $\begin{array}{l}\text { Jumlah } \\
\text { (Orang) }\end{array}$ & $\begin{array}{c}\text { Persentase } \\
(\%)\end{array}$ & $\begin{array}{l}\text { Jumlah } \\
\text { (Orang) }\end{array}$ & $\begin{array}{c}\text { Persentase } \\
(\%)\end{array}$ & $\begin{array}{l}\text { Jumlah } \\
\text { (Orang) }\end{array}$ & $\begin{array}{c}\text { Persentase } \\
(\%)\end{array}$ \\
\hline \multicolumn{7}{|l|}{ Kelompok Umur (Tahun) } \\
\hline $20-30$ & 1 & 20 & 5 & 63 & 0 & \\
\hline $30-40$ & 1 & 20 & 0 & 0 & 0 & \\
\hline $41-50$ & 1 & 20 & 1 & 13 & 8 & 80 \\
\hline$>50$ & 2 & 40 & 2 & 25 & 2 & 20 \\
\hline \multicolumn{7}{|l|}{ Tingkat Pendidikan } \\
\hline SD & 1 & 20 & 2 & 25 & 0 & \\
\hline SMP & 2 & 40 & 1 & 13 & 3 & 30 \\
\hline SMA & 1 & 20 & 3 & 38 & 7 & 70 \\
\hline $\begin{array}{l}\text { Perguruan Tinggi } \\
\text { Jumlah Karyawan }\end{array}$ & 1 & 20 & 2 & 25 & 0 & \\
\hline 0 & 3 & 60 & 6 & 75 & 10 & 100 \\
\hline $1-2$ & 2 & 40 & 2 & 25 & & \\
\hline$>2$ & & & & & & \\
\hline
\end{tabular}




\section{SALURAN PEMASARAN CABAI RAWIT MERAH}

Saluran pemasaran cabai rawit merah di Desa Cidatar dimulai dari petani yang menjual produknya ke pedagang pengumpul desa dengan alasan karena adanya kemudahan yang menghemat biaya dalam hal pemasaran. Selain itu, petani menjual cabai rawit merah ke pedagang pengumpul desa karena volume panen tidak terlalu banyak untuk langsung dijual ke pasar. Saluran pemasaran cabai rawit merah di Desa Cidatar secara rinci dapat dilihat pada Gambar 2. Terdapat lima saluran pemasaran cabai rawit merah yaitu:

1. Petani - Pedagang pengumpul desa - Pedagang besar Pasar Induk Kramat Jati Jakarta Pedagang Pengecer - Konsumen akhir.

2. Petani - Pedagang pengumpul desa - Pedagang besar Pasar Induk Cikajang Garut - Pedagang Pengecer - Konsumen akhir.

3. Petani - Pedagang pengumpul desa - Pedagang besar Pasar Induk Cikajang Garut - Pedagang besar Pasar Induk Kramat Jati Jakarta Pedagang pengecer - Konsumen akhir.

4. Petani - Pedagang pengumpul desa - Pedagang besar Pasar Induk Caringin Bandung Pedagang pengecer - Konsumen akhir.

5. Petani - Pedagang pengumpul desa - Pedagang besar Pasar Induk Caringin Bandung Pedagang besar Pasar Induk Kramat Jati Jakarta - Pedagang Pengecer - Konsumen akhir.
Berdasarkan kelima saluran pemasaran tersebut, terlihat bahwa 100 persen cabai rawit merah dipasarkan melalui pedagang pengumpul desa.

Semua saluran pemasaran dimulai dari petani yang menjualnya cabai rawitnya ke pedagang pengumpul desa. Pedagang pengumpul desa biasanya mensortir cabai rawit merah yang telah mereka beli dan dikemas dengan menggunakan karung bervolume sekitar $80 \mathrm{Kg}$ sebelum menjualnya kepada pihak pedagang besar. Beberapa pedagang pengumpul desa akan menjual cabai rawit merah ke Pasar Induk Kramat Jati saat volume cabai telah tercapai yaitu sekitar 2 ton. Hal ini dilakukan untuk menghemat biaya transportasi. Untuk mencapai volume ini biasanya beberapa pedagang pengumpul desa melakukan kerjasama lalu bersama-sama menyewa mobil untuk mengangkut cabai ke Pasar Induk Kramat Jati Jakarta. Namun, untuk pedagang pengumpul desa yang sudah memiliki kendaraan seperti truk atau pick up mereka tidak melakukan kerjasama dengan pedagang pengumpul desa lainnya karena berapapun volume cabai rawit yang didapat akan diangkut bersamaan dengan produk-produk pertanian lainnya ke Pasar Induk Kramat Jati. Jika volume cabai rawit tidak banyak maka PPD biasanya akan menjual cabai rawit merah ke Pasar Induk Cikajang atau Pasar Induk Caringin. Dari Garut ke Pasar Induk Kramat Jati membutuhkan biaya transportasi sekitar Rp1.000.000 meng-

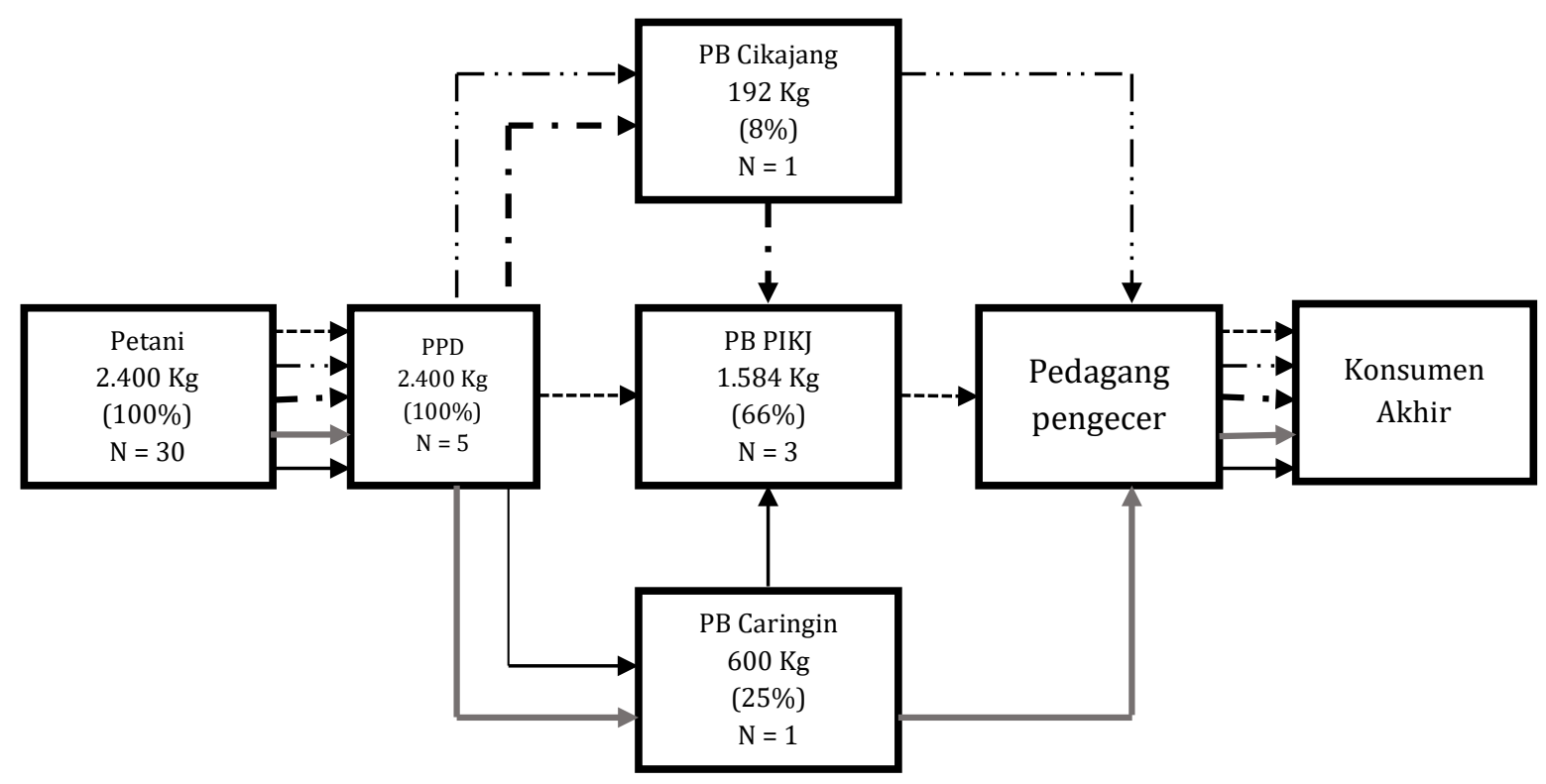

Gambar 2. Pola Saluran Pemasaran Cabai Rawit Merah di Desa Cidatar 
gunakan truk, namun biaya ini tidak hanya untuk mengangkut cabai rawit merah saja tetapi produk pertanian lainnya seperti bawang, tomat, kentang, petsai dll. Biaya ini merupakan biaya gaji karyawan, bensin, dan retribusi. Harga yang terjadi antara pedagang pengumpul desa dengan pedagang besar di Pasar Induk Keramat Jati sangat bervariasi. Biaya transportasi dari lokasi PPD ke Pasar Induk Cikajang dan Caringin membutuhkan biaya Rp5.000 - Rp10.000 per karung cabai rawit merah. Margin yang diperoleh pedagang pengumpul desa sekitar Rp2.000 Rp3.000/kg. Harga ini digunakan sebagai patokan pedagang pengumpul desa dalam menetapkan harga beli kepada para petani.

Pedagang besar pada melakukan aktivitas pembelian tidak terfokus pada komoditas cabai rawit merah saja, namun juga melakukan pembelian terhadap komoditas sayuran lainnya seperti bawang merah, bawang putih, cabai rawit hijau, cabai merah besar dan cabai rawit merah. Para pedagang besar di pasar induk juga melakukan kegiatan penyortiran cabai rawit merah yang telah mereka beli dari pedagang pengumpul desa sebelum menjualnya kepada pihak pedagang pengecer.

Beberapa pedagang besar di pasar induk memberikan batas minimal pembelian sebanyak 5 kilogram kepada pihak pedagang pengecer. Hal ini dilakukan agar cabai rawit cepat habis karena cabai yang baru akan datang besok sehingga mereka tidak ingin ada cabai yang tidak laku hari itu juga. Saat harga sedang mahal, cabai rawit merah yang busuk (hasil dari kegiatan penyortiran) dijual setengah harga bahkan lebih murah kepada para konsumen yang berprofesi sebagai pedagang gerobak seperti tukang bakso dan tukang siomai sedangkan saat harga sedang murah maka cabai rawit merah yang busuk langsung dibuang.

Dari pedagang besar, cabai rawit akan dijual ke pedagang pengecer. Harga yang terjadi antara pedagang besar dengan pedagang pengecer berfluktuatif setiap harinya bahkan per jamnya. Hal ini tergantung dari jumlah pasokan dan permintaan di pasar. Dari pedagang pengecer akan dijual ke konsumen akhir Jakarta.

\section{ANALISIS MARJIN PEMASARAN}

Analisis marjin dihitung berdasarkan pengurangan harga jual dengan harga beli pada setiap lembaga pemasaran cabai rawit merah. Marjin pemasaran dihitung dengan melihat besarnya biaya pemasaran cabai rawit merah dan keuntungan yang diambil oleh lembaga pemasaran yang terlibat. Biaya pemasaran merupakan biaya yang dikeluarkan dalam memasarkan cabai rawit merah hingga ke konsumen akhir. Jenis biaya yang dikeluarkan setiap lembaga pemasaran berbeda-beda meliputi biaya pengangkutan, pengemasan, tenaga kerja, retribusi, dan penyusutan, dan sewa lapak. Sedangkan keuntungan pemasaran merupakan selisih antara harga jual dengan harga beli dikurangi dengan biaya pemasaran oleh lembaga pemasaran yang terlibat.

Berdasarkan total marjin yang diperoleh pedagang perantara, marjin pemasaran terbesar terdapat pada saluran III yaitu sebesar Rp32.955 lalu diikuti saluran ke $\mathrm{V}$ dengan marjin pemasaran sebesar Rp 31.786. Saluran I yang menuju Pasar Induk Kramat Jati memiliki marjin pemasaran sebesar Rp30.167. Selanjutnya saluran IV memiliki marjin pemasaran sebesar Rp27.202 dan marjin pemasaran terendah pada saluran II yakni sebesar Rp 21.455. Saluran I merupakan saluran yang pendistribusian cabai rawit merah paling banyak karena Pasar Induk Keramat Jati yang merupakan pasar acuan dari seluruh pasar induk yang ada di Jabodetabek.

Berdasarkan hasil yang diperoleh dapat disimpulkan panjang pendeknya saluran rantai pemasaran menentukan marjin yang dihasilkan. Besar marjin yang dihasilkan untuk setiap saluran pemasaran juga ditentukan oleh jarak lokasi pemasaran.

\section{ANALISIS FARMER'S SHARE}

Analisis farmer's share merupakan perbandingan harga yang diterima oleh petani cabai rawit merah dengan harga yang dibayar oleh konsumen akhir. Analisis farmer's share merupakan salah satu indikator untuk menentukan efisiensi operasional pemasaran suatu komoditas.

Berdasarkan data yang tersaji pada Tabel 5 menunjukkan bahwa bagian terbesar yang diterima petani terdapat pada saluran II yaitu sebesar 48 persen. Saluran I dan IV memiliki nilai 
Tabel 5. Nilai Efisiensi Pemasaran pada Masing-masing Pola Saluran Pemasaran Cabai Rawit Merah di Desa Cidatar

\begin{tabular}{|c|c|c|c|c|c|c|}
\hline $\begin{array}{c}\text { Saluran } \\
\text { Pemasaran }\end{array}$ & $\begin{array}{c}\text { Volume } \\
\text { (Bulan/Kg) }\end{array}$ & $\begin{array}{c}\text { Harga } \\
\text { (Rp/kg) }\end{array}$ & $\begin{array}{c}\text { Total Biaya } \\
\text { (Rp/kg) }\end{array}$ & Marjin & $\begin{array}{c}\text { Farmer's } \\
\text { Share (\%) }\end{array}$ & $\Pi \mathrm{\Pi i} / \mathrm{Ci}$ \\
\hline I & 2.400 & 22.333 & 7.658 & 57,5 & 43 & 4,33 \\
\hline II & 1.000 & 19.545 & 6.600 & 52,3 & 48 & 3,66 \\
\hline III & 1.000 & 19.545 & 6.967 & 62,8 & 37 & 5,64 \\
\hline IV & 1.120 & 20.714 & 6.963 & 56,8 & 43 & 4,48 \\
\hline V & 1.120 & 20.714 & 7.329 & 60,5 & 39 & 4,96 \\
\hline
\end{tabular}

Sumber: Data Primer (2018) diolah

farmer's share yang sama yaitu sebesar 43 persen kemudian diikuti saluran pemasaran $\mathrm{V}$ yang memiliki nilai farmer's share sebesar 39 persen. Saluran III merupakan saluran dengan nilai farmer's share terendah yakni sebesar 37 persen. Besaran nilai farmer's share ini ditentukan oleh marjin pemasaran yang diambil oleh pihak pedagang pengumpul desa, pedagang besar dan pedagang pengecer.

\section{ANALISIS RASIO KEUNTUNGAN DAN BIAYA PEMASARAN}

Pada saluran I, pedagang pengecer mengeluarkan biaya pemasaran sebesar Rp3.100 dengan keuntungan yang diperoleh oleh pedagang pengecer sebesar Rp19.692 per kilogram. Besarnya keuntungan yang diambil oleh pedagang pengecer ini dikarenakan mereka menjualnya dengan cara eceran sehingga keuntungannya menjadi lebih besar namun juga risiko barang yang tidak laku menjadi meningkat. Besarnya keuntungan yang diperoleh pedagang besar di Pasar Induk Kramat Jati adalah Rp1.758 per kilogram dengan biaya pemasaran sebesar Rp700 per kilogram. Pedagang besar di Pasar Induk Kramat Jati melakukan perlakuan biaya yang lebih banyak dan cukup besar dibandingkan pedagang pengumpul desa seperti biaya pengangkutan, pengemasan, tenaga kerja, retribusi, penyusutan, bongkar muat, dan biaya sewa lapak. Biaya penyusutan merupakan biaya pemasaran yang paling tinggi yang harus ditanggung oleh pedagang besar dan pedagang pengumpul desa. Total biaya yang dikeluarkan pada saluran I adalah Rp 7.658/Kg

Pada saluran II, pedagang pengecer mengeluarkan biaya pemasaran sebesar Rp3.100 dengan keuntungan yang diperoleh oleh pedagang pengecer sebesar Rp8.950 per kilogram. Besarnya keuntungan yang diambil oleh pedagang pengecer ini dikarenakan mereka menjualnya dengan cara eceran sehingga keuntungannya menjadi lebih besar namun juga risiko barang yang tidak laku menjadi meningkat. Besarnya keuntungan yang diperoleh pedagang besar di Pasar Induk Cikajang adalah Rp2.311 per kilogram dengan biaya pemasaran sebesar Rp367 per kilogram. Hal ini dikarenakan pedagang besar di Pasar Induk Cikajang melakukan perlakuan biaya yang lebih banyak dan cukup besar dibandingkan pedagang pengumpul desa seperti biaya pengangkutan, pengemasan, tenaga kerja, retribusi, penyusutan, bongkar muat, dan biaya sewa lapak. Biaya penyusutan merupakan biaya pemasaran yang paling tinggi yang harus ditanggung oleh pedagang besar dan pedagang pengumpul desa. Saluran pemasaran II memiliki nilai rasio keuntungan dan biaya sebesar 3,66. Total biaya yang dikeluarkan pada saluran II adalah sebesar Rp6.600 per kilogram.

Adapun saluran III memiliki nilai rasio keuntungan dan biaya sebesar Rp5.64 dengan total biaya pemasaran adalah Rp6.967 per kilogram yang dilakukan oleh petani, pedagang pengumpul desa, pedagang besar di Pasar Induk Cikajang, pedagang besar di Pasar Induk Keramat Jati, dan pedagang pengecer. Biaya pemasaran terbesar dikeluarkan oleh pedagang pengecer yaitu sebesar Rp3.100 per kilogram. Keuntungan terbesar juga diperoleh oleh pedagang pengecer yaitu sebesar Rp19.692 per kilogram, di mana keuntungan pemasaran yang diperoleh pedagang pengecer ini dikarenakan mereka menjual secara eceran per ons yang mengakibatkan barang lama laku terjual sehingga risiko penyusutan semakin tinggi. Pedagang pengumpul desa mendapat keuntungan pemasaran sebesar Rp5.594 per kilogram dengan biaya pemasaran sebesar Rp 1.133 per kilogram. 
Saluran pemasaran IV memiliki nilai rasio keuntungan dan biaya sebesar 4,48. Total biaya yang dikeluarkan pada saluran IV adalah sebesar Rp4.963 per kilogram yang dilakukan oleh petani, pedagang pengumpul desa, pedagang besar di Pasar Induk Caringin Bandung dan pedagang pengecer. Biaya pemasaran terbesar dikeluarkan oleh pedagang pengecer yaitu sebesar Rp3.100 per kilogram. Besarnya biaya pemasaran pada tingkat pedagang pengecer ini disebabkan mengeluarkan biaya pengangkutan, pengemasan, tenaga kerja. Keuntungan terbesar juga diperoleh oleh pedagang pengecer adalah sebesar Rp16.442 per kilogram. Pedagang pengumpul desa mendapat keuntungan pemasaran sebesar Rp2.361 per kilogram dengan biaya pemasaran sebesar Rp1.496 per kilogram. Keuntungan pemasaran pedagang besar Pasar Induk Caringin, yaitu sebesar Rp2.865 per kilogram dengan biaya pemasaran sebesar Rp367 per kilogram. Besarnya biaya pemasaran yang harus dikeluarkan oleh pedagang besar di Pasar Induk Caringin ini disebabkan pedagang besar di Pasar Induk Caringin melakukan perlakuan biaya yang lebih banyak dan cukup besar dibandingkan pedagang pengumpul desa seperti biaya pengangkutan, pengemasan, tenaga kerja, retribusi, penyusutan, bongkar muat, dan biaya sewa lapak.

Adapun saluran pemasaran $\mathrm{V}$, nilai rasio keuntungan dan biaya sebesar 4,96 total biaya pemasaran adalah Rp5.329. Saluran V melibatkan pedagang pengumpul desa, pedagang besar di Pasar Induk Caringin, pedagang besar di Pasar Induk Keramat Jati, dan pedagang pengecer. Biaya pemasaran terbesar dikeluarkan oleh pedagang pengecer yaitu sebesar Rp3.100 per kilogram. Besarnya biaya pemasaran pada tingkat pedagang pengecer ini disebabkan oleh tingginya biaya penyusutan yang harus ditanggung. Keuntungan terbesar juga diperoleh oleh pedagang pengecer yaitu sebesar Rp18.567 per kilogram. Pedagang pengumpul desa mendapat keuntungan pemasaran sebesar Rp2.361 per kilogram dengan biaya pemasaran sebesar Rp1.496 per kilogram. Keuntungan pemasaran terendah pada saluran ini terdapat pada pedagang besar di Pasar Caringin yaitu sebesar Rp2.865 per kilogram dengan biaya pemasaran sebesar Rp367 per kilogram.
Efisiensi merupakan salah satu tujuan yang hendak dicapai dalam suatu aktivitas pemasaran. Suatu saluran dikatakan efisien apabila penyebaran nilai rasio keuntungan terhadap biaya pada masing-masing lembaga pemasaran merata. Artinya setiap satu satuan rupiah biaya yang dikeluarkan oleh lembaga pemasaranakan memberikan keuntungan yang tidak jauh beda dengan lembaga pemasaran lainnya yang terdapat pada saluran tersebut.

Untuk mengetahui saluran pemasaran cabai rawit merah di Desa Cidatar yang paling efisien dapat ditinjau dari beberapa poin analisis terhadap pola pemasaran cabai rawit merah diantaranya margin pemasaran, farmer's share, rasio keuntungan dan biaya, volume cabai yang dapat diserap pasar serta harga dari produk tersebut. Selain itu dapat dilihat dari pola saluran pemasaran yang terbentuk, berjalannya fungsifungsi pemasaran, struktur pasar, dan perilaku pasar. Tabel 5 menyajikan data mengenai nilai efisiensi pemasaran pada setiap pola saluran pemasaran yang terbentuk. Volume terbesar dan harga tertinggi terdapat pada saluran I. Total biaya dan marjin terendah terdapat pada saluran pemasaran II. Farmer's share terbesar terdapat pada saluran II dan nilai rasio $\pi \mathrm{i} / \mathrm{Ci}$ terbesar terdapat pada saluran III.

Saluran pemasaran yang paling efisien adalah saluran I. Saluran I memang bukan tertinggi jika dilihat dari marjin, farmer's share maupun rasio $\pi \mathrm{i} / \mathrm{Ci}$ namun volume cabai rawit merah yang melalui saluran pemasaran I jumlahnya dua kali lipat dibandingkan keempat saluran pemasaran lainnya dan dengan harga yang paling tinggi.

\section{SIMPULAN DAN SARAN}

\section{SIMPULAN}

Terdapat lima saluran pemasaran cabai rawit merah di Desa Cidatar yang melibatkan beberapa lembaga pemasaran yaitu petani, pedagang pengumpul desa (PPD), pedagang besar, dan pedagang pengecer.

Hasil analisis menunjukkan volume penjualan cabai rawit terbesar terdapat pada saluran pemasaran I dengan $2.400 \mathrm{Kg}$ dengan harga Rp22.333. Total biaya terbesar terdapat 
pada saluran pemasaran I yaitu sebesar Rp 7.658 dan total biaya terkecil terdapat pada saluran pemasaran ke II dengan Rp6.600/Kg. Marjin pemasaran terbesar terdapat pada saluran ke V dengan 60,5 persen sedangkan terkecil pada saluran II yaitu 52,3 persen. Farmer's share terbesar terdapat pada saluran II sebesar 48 persen dan rasio $\pi \mathrm{i} / \mathrm{Ci}$ terbesar terdapat pada saluran III sebesar 5,65. Saluran pemasaran I dinilai sebagai alternatif saluran yang efisien karena volume cabai rawit merah yang disalurkan besar dan dengan harga yang paling tinggi di antara saluran pemasaran lainnya.

\section{SARAN}

Rekomendasi saluran pemasaran yang sebaiknya dilakukan petani adalah saluran pemasaran I karena saluran pemasaran tersebut merupakan saluran dengan volume cabai paling besar yang dapat diserap oleh pasar dan dengan harga yang paling tinggi dibandingkan dengan saluran pemasaran lainnya. Kemudian, petani sebaiknya langsung menjual cabai rawit merah kepada pedagang di pasar induk agar mergin pemasaran lebih rendah dan bagain yang diterima petani akan lebih tinggi.

\section{DAFTAR PUSTAKA}

Asmarantaka RW. 2014. Pemasaran Agribisnis (Agrimarketing). Bogor: IPB Press

Dewi D.A, Darsono. 2018. Analisis Efisiensi Pemasaran Jagung (Zea mays) di Kabupeten Wonogiri. Journal Agriecobis. 2(1)

[Ditjen Hortikultura] Laporan Harian Harga Komoditas Pertanian. http://www.aplikasi.pertanian.go.id.

Jakarta. Diakses Desember 2018

[KEMENTAN] Kementerian Pertanian, 2018. Outlook komoditas pertanian subsektor holtikultura cabai. http://www.pertanian.go.id. Jakarta. Diakses Desember 2018

Nurhidayana. 2012. Analisis Efisiensi Pemasaran Cabai Merah di Kabupaten Batubara. Agrica (Jurnal Agribisnis Sumatera Utara). 5(1)
Pemprov DKI Jakarta, 2018. Report commodity. http://www.infopangan.jakarta.go.id. Jakarta. Diakses Desember 2018

Prayitno A.B, Hasyim A.I, Situmorang Suriaty. 2013. Efisiensi pemasaran cabai merah di Kecamatan Adiluwuh Kabupaten Pringsewu Provinsi Lampung. JIIA 1(1)

Puspita I.R, Wardhani R. 2013. Analisa efisiensi pemasaran komoditi cabai (Capsicum annum L) pada beberapa saluran pemasaran di Kota Madiun. Agritek. 14(1):72-86 